\title{
PENGEMBANGAN MODEL PENGUATAN LEMBAGA PERTANIAN SEBAGAI PRIME MOVER PEMBANGUNAN KAWASAN DAERAH PENYANGGA PEMBANGUNAN (DPP) DESTINASI WISATA KINTAMANI - BALI
}

\author{
Putu Gede Parma \\ Jurusan Perhotelan, Fakultas Ekonomi dan Bisnis Universitas Pendidikan \\ Ganesha \\ Singaraja, Indonesia
}

e-mail: parma1708@yahoo.com

\begin{abstract}
Abstrak
Tujuan pokok penelitian ini 'mengembangkan model prime mover sektor pertanian argo di daerah penyangga pembangunan (DPP) destinasi wisata Kintamani untuk penguatan dan pemberdayaan para petani agro berbasis kewilayahan dan berbasis penguatan kelembagaan lokal di Kecamatan Kintamani Kabupaten Bangli". Penelitian ini menggunakan desain penelitian dan pengembangan (R\&D) dengan metode kuantitatif IG (Indeks Gravitasi) untuk melihat derajat keterkaitan aktivitas ekonomi antara DPP dan desa sekitarnya, CDSF (Cobb-Douglas Stochastic Frontier) untuk melihat tingkat efisiensi teknis yang mencerminkan sejauhmana kegiatan produksi sektor dominan di DPP mencapai titik optimumnya, serta metode EL (Ekonometrik Logit) untuk mengetahui adakah fragmentasi produksi DPP dengan desa sekitarnya. Dalam penyusunan desain pola pengembangan ekonomi di DPP mengacu pada temuan studi pendahuluan dan trending analysis terkait dengan keunggulan potensi, permasalahan yang paling urgen, dan peluang usaha di masing-masing wilayah. Produk penelitian ini adalah : (1) peta permasalahan dan produksi dominan petani agro, (2) peta kelembagaan petani agro, (3) model pelembagaan petani agro, (4) draft model prime mover sektor pertanian agro terhadap pengembangan destinasi wisata, dan (5) artikel ilmiah (jurnal terakreditasi). Hasil penelitian menunjukkan bahwa : (1) berdasarkan data Dinas Pariwisata Kabupaten Bangli Provinsi Bali, yaitu : Desa Batur Selatan, desa Songan A, desa Songan B,dan desa Kedisan. Secara umum lembaga-lembaga social kemasyarakatan yang ada di semua desa tersebut hamper sama,hanya struktur organisasinya yang sedikit berbeda, yang disesuaikan dengan kebutuhan dan kebiasaan masyarakat setempat. (2) lembaga social dan budaya yang terdapat di desa-desa kawasan agrowisata Kintamani, pada umumnya adalah : sekehe teruna teruni, kelompok tani, gabungan kelompok tani, sekehe jogged, sekehe santi, sekehe tabuh, sekehe payus, sekehe rejang,sekehe manyi, sekehe baris, sekehe pruguh, sekehe gong, sekehe gambuh, lembaga perkreditan desa, desa adat, prajuru desa adat, koperasi unti desa,kelompok penyakap,dan kelompok peternak. (3) pada desa-desa kawasan agrowisata di Kintamani, terdapat lahan yang masih cukup besar untuk dimaksimalkan pemanfaatannya, yakni berkisar antara 10 sampai 100 hektar di setiap desanya. Namun, berdasarkan hasil survey di lapangan, hanya sebagian kecil dari lahan tersebut yang merupakan milik penduduk setempat. (4) potensi
\end{abstract}


kawasan Kintamani pada dasarnya bersandar pada keindahan alam dan modalitas social budaya masyarakat itu sendiri. (5) masih ditemukan berbagai kendala yang dihadapi oleh masyarakat desa kawasan agrowisata pada umumnya dan petani pada khusnya, terutama pada aspek-aspek khusus, seperti: aturan desa dan pengelolaan lembaga sosial dan budaya desa, luas dan kepemilikan lahan, system permodalan, pemanfaatan sumber daya, dan system penjualan.

Kata kunci : pemberdayaan, petani agro, tricle-down effects, destinasi wisata,prime mover

\begin{abstract}
The main objective of this study is: 'Developing a model of the agricultural sector agro prime mover in the development buffer (DPP) Kintamani tourism destinations for the strengthening and empowerment of farmers base agro - based regional institution building in the district of Kintamani district local Bangli". This research use the design research and development ( $R$ \& $D$ ) by quantitative methods IG index (Gravity) to see the degree of linkage of economic activity between the DPP and the villages around it, CDSF (Cobb-Douglas Stochastic Frontier) to see the level of technical efficiency which reflects the extent of production dominant sector in the DPP reaches its optimum point, and the method of EL (Economic Logit) to know is there any fragmentation of production between the DPP with the surrounding villages. In the preparation of the design pattern of economic development in the DPP will refer to the findings of a preliminary study and trending analysis related to the potential advantages, the most urgent problems, and opportunities in each region, products of each research are : (1) map issues and farmers dominant agro production, (2) agro map farmer institution, (3) model of institutionalizing agro farmers, (4) a draft model of the agricultural sector agro prime mover for the development of tourist destinations, and (5) scientific articles (accredited journals). Enelitian results show that : (1) based on data from the Department of Tourism Bangli, there are some villages that have been estabilished as a tourist Central, North Batur village, Kedisan village, the village of Fruits, Trunyan, Suter village, the village Songan A, B Songan village, and the the village Kedisan. In the general,social institution that exist in all villages is almost the same, just a slighty different organizational structure, tailored to local needs and customs. (2) social and cultural institutions located in the villages of Kintamani agrotourism, in general, are : sekehe cadet teruni, farmers group, rejang group, sekehe Manyi, sekehe line, sekehe pruguh,sekehe gong,sekehe gambuh, rural credit institutions, indigenous villages, prajuru indigenous village, the village unit cooperatives, penyakap groups and farmers groups. (3) in the village of agrotourism in Kintamani, there is land that is still big enough to be maximized, which range from 10 to 100 acres in each village. However, based on the results of the survey in the field, only a small portion of the land that tourism in Kintamani area basically rely on the beauty of nature and modalities of social culture itself. (5) and found to the various constraints faced by rural communities agrowisata region in general and farmers in particular, especially on special aspek-aspek, such as : the rules of the village and the management of social institutions and cultural village, spacious and land tenure systems,capital,resource utilization, and sales system.
\end{abstract}


Keywords : empowerment, farmers agro tricle-down effects, tourist destinations, prime mover

\section{PENDAHULUAN}

Kelembagaan petani memiliki titik strategis (entry point) dalam mengerakkan sistem agribisnis di pedesaan. Untuk itu segala sumberdaya yang ada di pedesaan perlu diarahkan/ diprioritaskan dalam rangka peningkatan profesionalisme dan posisi tawar petani (kelompok tani). Realitasnya, masih jauh dari penegasan tujuan pembangunan sektor pertanian di atas. Hal ini sebagaimana yang dialami oleh kalangan petani di kawasan agrowisata Kintamani- Bangli. Permasalahan pokok yang masih melekat pada soso petani dan kelembagaan petani di Kecamatan Kintamani Kabupaten Bangli adalah : (1) minimnya wawasan dan pengetahuan mereka terhadap masalah manajemen produksi maupun jaringan pemasaran, (2) belum terlibatnya secara utuh para petani dalam kegiatan agrowisata, karena aktivitas mereka masih terfokus pada kegiatan produksi (on farm), dan (3) peran dan fungsi kelembagaan petani sebagai wadah organisasi petani yang telah ada, belum berjalan secara optimal. Untuk mengatasi permasalahan tersebut, perlu dilakukan upaya pengembangan pemberdayaan, dan penguatan kelembagaan petani di kawasan agrowisata Kintamani Kabupaten Bangli, (seperti: kelompok tani, lembaga tenaga kerja, kelembagaan penyedia input, kelembagaan output, kelembagaan penyuluh, dan kelembagaan permodalan), yang diharapkan dapat meningkatkan bargaining position mereka dalam struktur pembangunan pariwisata di daerah tersebut. Tindakan perlindungan sebagai keberpihakan kepada petani tersebut, baik sebagai produsen maupun penikmat hasil jerih payah usaha tani mereka terutama diwujudkan melalui tingkat harga output yang layak dan menguntungkan petani itu sendiri. Dengan demikian, penguatan dan pemberdayaan kelembagaan tersebut juga dimaksudkan untuk menghasilkan pencapaian kesinambungan dan keberlanjutan daya dukung sumber daya alam dan berbagai usaha untuk menopang dan menunjang aktivitas kehidupan pembangunan pertanian di kawasan wisata Kintamani. Oleh karena itu, diperlukan kelembagaan ekonomi pedesaan yang mampu memebrikan kekuatan bagi petani (posisi tawar yang tinggi). Kelembagaan pertanian dalam hal ini diharapkan mampu memberikan jawaban atas permasalahan diatas. Penguatan posisi tawar petani melalui kelembagaan merupakan suatu kebutuhan yang sangat mendesak dan mutlak diperlukan oleh petani, agar mereka dapat bersaing dalam melaksanakan kegiatan usaha tani dan dapat meningkatkan kesejahteraan hidupnya. Berdasarkan latar belakang di atas maka tujuan penelitian ini secara rinci dapat dijabarkan sebagai berikut: (1) mengidentifikasikan dan memetakan lembaga-lembaga sosial kemasyarakatan yang telah ada di desa adat yang termasuk sebagai wilayah destinasi wisata Kintamani Kabupaten Bangli. (2) mengidentifikasi sumber daya dan potensi lokal unggulan sektor pertanian yang dimiliki oleh masyarakat petani agrowisata di kawasan destinasi wisata Kintamani Kabupaten Bangli- Bali (3) mengidentifikasikan dan 
memformulasikan berbagai persoalan yang selama ini dihadapi oleh kalangan petani agrowisata di kawasan destinasi wisata Kintamani Kabupaten BangliBali. (4) mengembangkan model kelembagaan petani agro berbasis kewilayahan untuk membangun dan menciptakan ketahanan sosial masyarakat petani agrowisata di kawasan destinasi wisata Kintamani Kabupaten Bangli-Bali.

mengembangkan model penguatan lambaga lokal pertanian yang mampu mendorong terjadinya prime mover sector pertanian bagi pemandirian masyarakat setempat dan masyarakat sekitarnya di kawasan destinasi wisata Kintamani Kabupaten Bangli-Bali. Mencermati berbagai manfaat penempatan sektor pertanian sebagai penggerak utama perekonomian merupakan suatu peluang yang sangat besar sekaligus beban atau liabilities. Dengan masih banyaknya masyarakat yang bernaung di bawah sektor pertanian, dengan tingkat pendidikan rata-rata dan produktivitas yang relative rendah dan skala lahan yang terbatas serta tingkat kemiskinan yang relatif lebih tinggi dibanding dengan sektor lain, maka hal ini merupakan tantangan yang sangat besar. Selain itu, pembangunan yang bertumpu pada sumber daya alam saja akan mempunyai tingkat pengembangan yang sangat terbatas dan tidak dapat menciptakan increment sebesar yang dapat diberikan oleh sektor manufaktur dan sektor jasa. Diversifikasikan usaha dapat menstabilkan pendapatan dari sektor pertanian yang fluktuatif dan relatif dipengaruhi musim, namun tetap belum dapat menghasilkan lonjakan nilai tambah yang dibutuhkan dalam perekonomian suatu Negara. Pengembangan produk unggulan dan eksotik dapat meningkatkan diferensiasi produk, namun juga belum dapat diharapkan memberikan tambahan pendapatan yang secara nasional signifikan. Dengan kata lain, jika sektor petanian masih bergerak di tingkat primer (on-farm) semata-mata, maka akan sulit untuk dapat dijadikan prime mover pertumbuhan ekonomi nasional. Pertanyaan kemudian adalah, strategi apa yang diharapkan untuk dapat menciptakan lonjakan tambahan pendapatan ekonomi dengan tetap bertumpu pada sektor pertanian. Jawabannya adalah dengan tetap bertumpu pada sektor pertanian namun mengembangkan produk pertanian ke tingkat yang lebih tinggi pada industrial ladder, dikenal sebagai agroindustri. Sektor pertanian tidak akan pernah lepas dari fungsinya sebagai sumber utama untuk penyediaan bahan pangan. Dalam meningkatkan ketahanan pangan, tantangan besar saat ini adalah konsumsi masih bertumpu pada beras. Strategi baru yang dikembangkan adalah penerapan social engineering terhadap konsumen dengan mencoba mengubah budaya dan perilaku makan beras, menjadi budaya mengkonsumsi pangan yang memenuhi standar gizi (Atmadja, 2010). Upaya ini akan lambat, namun perubahan selera dan perilaku memang proses yang bersifat gradual. Dengan demikian, tekanan terhadap beras sebagai satu- satunya atau mayoritas sumber kardohidrat akan makin terkurangi.

Pada saat ini, industrialisasi di bidang pertanian non- pangan masih sangat terbatas. Masalah utama adalah pasokan input dari sektor pertanian 
primer masih sangat terbatas, baik kualitas dan jumlah pasokan, serta ketetapan waktu. Dengan kebutuhan dan persyaratan industri semacam itu, sektor pertanian primer masih belum dapat menyelaraskan dengan dinamika industri pengolahan. Diperlukan pembangunan kelembagaan untuk dapat meningkatkan pengelolaan produksi pertanian non-pangan untuk dapat memasuki era industrilisasi. Sementara itu, bidang perkebunan masih perlu dikembangkan industri pengolahannya. Dengan masih tetap bergeraknya ekspor produk perkebunan di tingkat primer, sudah mulai mendapatkan persaingan dari negaranegara penghasil produk perkebunan yang baru. Produksi minyak sawit sudah jauh tertinggal oleh Malaysia, sementara produksi minyak mentah sudah disaingi oleh India dan Thailand. Sektor jasa pendukung pertanian misalnya bidang pemasaran dan angkutan juga masih didominasi oleh negara asing, sehingga nilai tambah juga diperoleh negaranegara tersebut. Pengembangan jasa agribisnis masih merupakan bidang yang perlu dikembangkan. Kelembagaan pertanian dalam hal ini mampu memberikan jawaban atas permasalahan di atas. Penguatan posisi tawar petani melalui kelembagaan merupakan suatu kebutuhan yang sangat mendesak dan mutlak diperlukan oleh petani, agar mereka dapat bersaing dalam melaksanakan kegiatan usaha tani dan dapat meningkatkan kesejahteraan hidunpnya. Petani jika berusaha tani secara individu akan terus berada di pihak yang lemah karena petani secara individu akan mengelola usaha tani dengan luas garapan kecil dan terpencar serta kepemilikan modal yang rendah. Kelembagaan petani di daerah pedesaan, umumnya tidak berjalan dengan baik disebabkan oleh beberapa faktor, yaitu : (1) kelompok tani pada umumnya dibentuk berdasarkan kepentingan teknis untuk memudahkan pengkoordinasian apabila ada kegiatan atau program pemerintah, sehingga lebih bersifat orientasi program, dan kurang menjamin kemandirian kelompok dan keberlanjutan kelompok, (2) partisipasi dan kekompakan anggota kelompok dalam kegiatan kelompok relatif rendah.ini tercermin dari tingkat kehadiran anggota dalam pertemuan kelompok rendah, (3) pengelolaan kegiatan produktif anggota kelompok bersifat inividu. Kelompok sebagai forum kegiatan bersama belum mampu menjadi wadah pemersatu kegiatan anggota dan pengikat kebutuhan anggota secara bersama, sehingga kegiatan produktif individu lebih menonjol, (4) pembentukan dan pengembangan kelembagaan tidak menggunakan basis sosial capital setempat dengan prinsip keotonomian dan pemberdayaan,(5) pembentukan dan pengembangan kelembagaan berdasarkan konsep cetak biru (blue print approach) yang seragam. Introduksi kelembagaan dari luar kurang memperhatikan struktur dan jaringan kelembagaan lokal yang telah ada, serta kekhasan ekonomi,sosial, dan politik yang berjalan, (6) pembentukan dan pengembangan kelembagaan berdasarkan pendekatan yang top down, menyebabkan tidak tumbuhnya partisipasi masyarakat, kelembagaan-kelembagaan yang dibangun terbatas hanya untuk memperkuat ikatan horizontal, bukan 
ikatan vertikal, dan (8) pengembangan kelembagaan selalu menggunakan jalur structural, dan lemah dari pengembangan aspek kulturalnya.

(Syahyuti, 2003;Purwanto,dkk,2007).

Permasalahan yang dihadapi petani pada umumnya adalah lemah dalam hal permodalan. Akibatnya tingkat penggunaan saprodi rendah, inefisien skala usaha karena umumnya berlahan sempit, dan karena terdesak masalah keuangan posisi tawar ketika panen lemah. Selain itu, produk yang dihasilkan petani relatif berkualitas rendah, karena umumnya budaya petani di pedesaan dalam melakukan praktik pertanian masih berorientasi pada pemenuhan kebutuhan keluarga (subsistem), dan belum berorientasi pasar. Selain masalah internal petani tersebut,ketersediaan faktor pendukung seperti infrastruktur, lembaga ekonomi pedesaan,intensitas penyuluhan,dan kebijakan pemerintah sangat diperlukan, guna mendorong usaha tani dan meningkatkan akses petani terhadap pasar (Saragih,2002).

Perumusan format upaya pemberdayaan masyarakat desa haruslah berbasis pada dua prinsip dasar pendekatan. Yang pertama, bagaimana menciptakan peluang tersebut. Upaya pemberdayaan desa seyogianya tidak dilakukan dengan berbasis pada suatu grand scenario karena hal seperti itu tidak pernah mampu memberikan hasil yang diharapkan. Pemberdayaan kelembagaan yaitu : (1) kelembagaan lokal tradisional yang hidup dan eksis dalam komunitas (voluntary sector ), (2) kelembagaan pasar (private sector) yang dijiwai ideology ekonomi terbuka, dan (3) kelembagaan sistem politik atau pengambilan keputusan di tingkat public (public sector).

\section{METODE PENELITIAN}

Secara akademis, penelitian ini menggunakan desain penelitian dan pengembangan yang diintegrasikan dengan metode Kuantitatif Indeks Gravitasi ( KIG ) untuk melihat derajat keterkaitan aktivitas ekonomi antara DPP dan desa adat sekitarnya, metode CDSF (Cobb- Douglas Stochastic Frontier ) untuk melihat tingkat efisiensi teknis yang mencerminkan sejauhmana kegiatan produksi sektor pertanian agro di DPP mencapai titik optimumnya, dan metode Ekonometrik Logit ( $E L$ ) untuk mengetahui adakah fragmentasi produksi diantara DPP dengan desa adat sekitar. Secara skematis tahapan, metode, indikator capaian, dan produk dari penelitian ini dalam setiap tahunnya dapat dijabarkan sebagai berikut.

Tabel 1 Kegiatan Penelitian

\begin{tabular}{|c|c|c|c|}
\hline FASE & KEGIATAN PENELITIAN & METODE & PRODUK/ LUARAN \\
\hline $\begin{array}{l}\text { Analisis } \\
\text { kebutuhan } \\
\text { dan } \\
\text { pemetaan } \\
\text { (2012) }\end{array}$ & $\begin{array}{l}\text { 1. Identifikasi } \\
\text { permasalahan pokok } \\
\text { petani agro } \\
\text { 2. Identifikasi kawasan } \\
\text { (kluster) desa adat } \\
\text { sebagai DPP } \\
\text { 3. Identifikasi dan }\end{array}$ & $\begin{array}{l}\text { - } \text { Studi } \\
\text { dokumentasi } \\
\text { - } \text { Wawancara } \\
\text { - Observasi } \\
\text { - } \text { Focuss group } \\
\text { Discussion } \\
\text { - Indeks Graviti }\end{array}$ & $\begin{array}{l}\text { - Peta } \\
\text { permasalahan } \\
\text { pokok petani agro } \\
\text { - Peta klasifikasi } \\
\text { komoditas wilayah } \\
\text { DPP } \\
\text { - Peta kelembagaan }\end{array}$ \\
\hline
\end{tabular}




\begin{tabular}{|c|c|c|c|}
\hline & $\begin{array}{l}\text { pemetaan } \\
\text { produk/komoditi } \\
\text { unggulan masing- } \\
\text { masing desa adat } \\
\text { 4. ldentifikasi dan } \\
\text { kelembagaan kluster } \\
\text { permodalan } \\
\text { DPP } \\
\text { 5. Analisis kebutuhan } \\
\text { dasar masing-masing } \\
\text { kluster DPP } \\
\text { 6. Pengembangan } \\
\text { kelembagaan pertanian } \\
\text { 7. Pengembangan draft } \\
\text { model tricle down } \\
\text { effects DPP } \\
\text { 8. Pengembangan pola } \\
\text { sinergi potensi antara } \\
\text { DPP,Pemda,Desa } \\
\text { Adat, dan Lembaga } \\
\text { Perbankan }\end{array}$ & $\begin{array}{ll}\text { - } & \text { KIG) } \\
\text { CDSF(Codd- } & \text { Douglas } \\
\text { Stochastic } \\
\text { Frontier) } \\
\text { - } & \text { Ekonometrik } \\
& \text { Logit (EL) }\end{array}$ & $\begin{array}{ll} & \text { adat } \\
\text { - } & \text { Model } \\
\text { pelembagaan } \\
\text { petani agro } \\
\text { - } & \text { Artikel ilmiah(jurnal } \\
& \text { terakreditasi) } \\
\text { - } & \text { Laporan Penelitian }\end{array}$ \\
\hline $\begin{array}{l}\text { Pengemb } \\
\text { angan } \\
\text { model } \\
(2013)\end{array}$ & $\begin{array}{l}\text { 1. Pengembangan model } \\
\text { kelembagaan petani } \\
\text { agro berbasis } \\
\text { kewilayahan } \\
\text { 2. Pengembangan model } \\
\text { tricle down effects DPP } \\
\text { terhadap } \\
\text { pengembangan } \\
\text { destinasi wisata } \\
\text { Kintamani-Bali } \\
\text { 3. Pengembangan model } \\
\text { pemberdayaan petani } \\
\text { agro berbasis } \\
\text { kewilayahan } \\
\text { 4. Pengembangan model } \\
\text { rekayasa kebijakan } \\
\text { publik sektor pertanian } \\
\text { berbasi kewilayahan }\end{array}$ & $\begin{array}{ll}\text { - } & \text { Interrater } \\
& \text { validity model } \\
\text { - } & \text { Expert } \\
\text { judgement } \\
\text { - } & \text { Eksperimenta } \\
\text { si } \\
\text { - Indeks Graviti } \\
\text { (KIG) } \\
\text { - CDSF(Codd- } \\
\text { Douglas } \\
\text { Stochastic } \\
\text { Frontier) } \\
\text { - Ekonometrik } \\
\text { Logit (EL) }\end{array}$ & 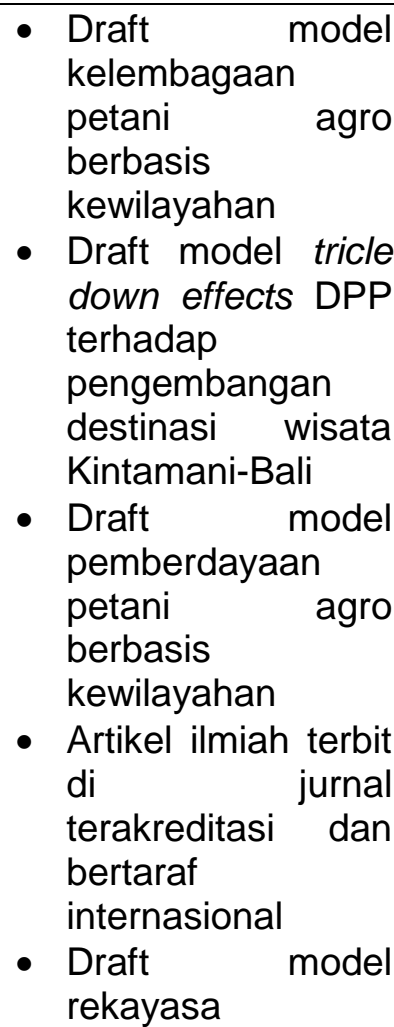 \\
\hline
\end{tabular}




\begin{tabular}{|c|c|c|c|}
\hline & & & $\begin{array}{l}\text { kebijakan public } \\
\text { sector pertanian } \\
\text { berbasis } \\
\text { kewilayahan } \\
\text { - Artikel ilmiah(jurnal } \\
\text { bertaraf } \\
\text { internasional) } \\
\text { - Laporan penelitian }\end{array}$ \\
\hline $\begin{array}{l}\text { Implement } \\
\text { asi dalam } \\
\text { pendampi } \\
\text { ngan } \\
(2014)\end{array}$ & $\begin{array}{l}\text { 1. Penerapan } \\
\text { kelembagaan petani } \\
\text { agro berbasis } \\
\text { kewilayahan } \\
\text { 2. Penerapan model tricle } \\
\text { down effects DPP } \\
\text { terhadap } \\
\text { pengembangan } \\
\text { destinasi wisata } \\
\text { Kintamani-Bali } \\
\text { 3. Penerapan model } \\
\text { pemberdayaan petani } \\
\text { agro berbasis } \\
\text { kewilayahan } \\
\text { 4. Penerapan model } \\
\text { rekayasa kebijakan } \\
\text { public sector pertanian } \\
\text { berbasis kewilayahan }\end{array}$ & $\begin{array}{ll}\text { - } & \text { Indeks } \\
\text { Gravitasi } \\
\text { (KIG) } \\
\text { - } \text { CDSF(Codd- } \\
\text { Douglas } \\
\text { Stochastic } \\
\text { Frontier) } \\
\text { - Ekonomerik } \\
\text { Logit (EL) } \\
\text { - Expert } \\
\text { Judgement } \\
\text { - SSH } \\
\text { (Satisfication } \\
\text { Stake } \\
\text { Holders) } \\
\text { Method }\end{array}$ & $\begin{array}{l}\text { - } \text { Model } \\
\text { kelembagaan } \\
\text { petani agro } \\
\text { berbasis } \\
\text { kewilayahan } \\
\text { - } \text { Model tricle down } \\
\text { effects DPP } \\
\text { terhadap } \\
\text { pengembangan } \\
\text { destinasi wisata } \\
\text { Kintamani-Bali } \\
\text { - Model petani agro } \\
\text { berbasis } \\
\text { kewilayahan } \\
\text { - Artikel ilmiah terbit } \\
\text { di jurnal } \\
\text { terakreditasi dan } \\
\text { bertaraf public } \\
\text { internasional } \\
\text { - Model rekayasa } \\
\text { kebijakan pubranian } \\
\text { sector pertan } \\
\text { berbasis } \\
\text { kewilayahan } \\
\text { Artikel ilmiah(jurnal } \\
\text { bertaraf } \\
\text { internasional) } \\
\text { Laporan penelitian }\end{array}$ \\
\hline
\end{tabular}

$\begin{array}{ll}\text { HASIL PENELITIAN DAN } & \begin{array}{l}\text { agrowisata Kintamani,pada umumnya } \\ \text { adalah : Sekehe Teruna Teruni, } \\ \text { PEMBAHASAN }\end{array} \\ \begin{array}{l}\text { Kelompok Tani,Gabungan Kelompok } \\ \text { Tani, Sekehe Joged, Sekehe Santi, }\end{array} \\ \begin{array}{l}\text { Hasil Penelitian } \\ \text { Lembaga sosial dan budaya yang }\end{array} \\ \begin{array}{l}\text { Sekehe Tabuh, Sekehe Payus, Sekehe } \\ \text { terdapat di desa-desa kawasan } \\ \text { Rejang, Sekehe Manyi, Sekehe Baris, }\end{array}\end{array}$


Sekehe Pruguh, Sekehe Gong, Sekehe Gambuh, Lembaga Perkreditan Desa, Desa Adat, Prajuru Desa adat, Koperasi Unit Desa, Kelompok Penyakap, dan Kelompok Peternak. Semua lembaga sosial budaya tersebut telah memiliki anggaran besar dan anggaran rumah tangga yang struktur organisasinya pada umumnya mengacu pada pola manajemen sederhana, yaitu hanya terdiri atas ketua, wakil ketua, sekretaris, dan bendahara, serta anggota. Hamper di semua organisasi belum membagi atau menghiasi strukturnya dengan bagian atau bidang dan jenisnya. Pada desa-desa kawasan agrowisata di Kintamani, terdapat lahan yang masih cukup besar untuk dimaksimalkan pemanfaatannya, yakni berkisar antara 10 sampai 100 hektar di setiap desanya. Namun, berdasarkan hasil survey di lapangan, hanya sebagian kecil dari lahan tersebut yang merupakan milik penduduk setempat. Sebagian besar pemilik usaha agrowisata yang memiliki lahan luas merupakan para pendatang atau penanam modal asing yang justru melihat kawasan ini sebagai kawasan yang menjanjikan dalam sektor pertanian. Pada kawasan agrowisata tersebut, terdapat berbagai potensi lokal yang patut dikembangkan pemberdayaannya. Jenis tanaman/komoditi yang menjadi produk unggulannya di daerah tersebut seperti sayur- mayor, tomat, dan jeruk. Selain jeruk, terdapat pula berbagai macam jenis buah-buahan, ketela, jagung, dan bawang yang merupakan hasil pertanian yang paling banyak dihasilkan di desadesa kawasan agrowisata tersebut. Hasil pertanian tersebut sebenarnya memiliki pasarnya sendiri, karena termasuk kebutuhan pangan pokok masyarakat Indonesia pada umumnya. Adapun hasil-hasil tersebut biasanya dipasarkan ke hotel/restoran yang terdapat di sekitar kawasan wisata tersebut atau bahkan sampai keluar Kintamani. Namun, yang sangat disayangkan, dan yang merupakan suatu kendala bagi para petani, sistem penjualan hasil panen yang dilakukan oleh petani yakni dengan sistem pajegang/ borong dan petik berkala yang lebih menguntungkan para tengkulak. Berdasarkan data Dinas Pariwisata Kabupaten Bangli, terdapat beberapa desa yang telah ditetapkan sebagai destinasi wisata Kintamani Kabupaten Bangli Provinsi Bali, yaitu: desa Batur Selatan, desa Batur Tengah, desa Batur Utara,desa Kedisan,desa Buahan,desa Trunyan, desa Suter, desa Songan A,desa Songan B, dan desa Kedisan. Secara umum lembagalembaga sosial kemasyarakatan yang ada di semua desa tersebut hamper sama, hanya struktur organisasinya yang sedikit berbeda, yang disesuaikan dengan kebutuhan dan kebiasaan masyarakat setempat. Semua desa yang terkategori ke dalam destinasi wisata Kintamani merupakan desa agraris dengan tipologi lahan kering dan merupakan perbukitan dengan sebagiannya adalah lembah-lembah yang sangat produktif bagi pengembangan pertanian dan perkebunan. Lembaga sosial dan budaya yang terdapat di desa-desa tersebut pada umumnya adalah: Sekehe Teruna Teruni, Kelompok Tani, Gabungan Kelompok Tani, Sekehe Joged, Sekehe Santi,Sekehe Tabuh, Sekehe Payus, Sekehe Rejang, Sekehe Manyi, Sekehe Baris, Sekehe, Pruguh,

Jurnal IImu Sosial dan Humaniora | 388 
Sekehe Gong, Sekehe Gambuh, Lembaga Perkreditan Desa, Desa Adat, Koperasi Unit Desa, Kelompok Penyakap,dan Kelompok Peternak. Semua lembaga sosial tersebut telah memiliki anggaran dasar dan anggaran rumah tangga yang struktur organisasinya pada umumnya mengacu pada pola manajemen sederhana, yaitu hanya terdiri atas ketua, wakil ketua, sekretaris, dan bendahara, serta anggota. Hampir di semua organisasi belum membagi atau menghiasi strukturnya dengan bagian atau bidang dan jenisnya.

Profil masyarakat pedagang acung menunjukan bahwa pedagang acung yang menjual souvenir di sekitar objek wisata Desa Penolokan, sudah sangat banyak hingga mencapai 107 orang. Jumlah ini tentu sangat banyak mengingat areal tempat jualan yang tidak terlalu luas, sehingga berdampak pada persaingan yang sangat ketat. Terlebih lagi dengan keterampilan dan kemampuan pedagang acung yang belum sesuai dengan kebutuhan wisatawan,serta jenis produk yang ditawarkan sama dengan souvenir yang dijual di tempat lain dengan harga yang lebih murah, sehingga sebagian besar pedagang acung penghasilannya yang didapat hanya untuk memenuhi kebutuhan sehari-hari. Profil wisatawan yang berkunjung ke objek sebagian besar merupakan wisatawan yang ikut dalam paket tur, namun ada juga yang datang dengan keinginan mereka dengan pengaturan perjalanan yang diatur sendiri. Pemandangan alam Gunung dan Danau Batur yang indah ternyata mampu menarik wisatawan pada objek tersebut telah menarik masyarakat lokal untuk ikut berperan sebagai pedagang acung. Namun, karena terlalu banyaknya pedagang acung dan kurang kreatifnya produk yang ditawarkan sebagai souvenir, tidak semua wisatawan yang mau membelinya. Wisatawan selain membutuhkan rasa nyaman dalam berwisata, juga membutuhkan produk yang mencerminkan kekhasan pada objek wisata Desa Penelokan.

dimiliki $\begin{gathered}\text { Potensi kekuatan yang } \\ \text { oleh masyarakat desa }\end{gathered}$
penyangga pembangunan pariwisata di kawasan Kintamani pada dasarnya bersandar pada keindahan alam dan modalitas social budaya masyarakat itu sendiri. Untuk kepentingan tersebut, masih terdapat beberapa hal yang mesti dilakukan oleh pemerintah setempat untuk menjadikan kawasan ini sebagai destinasi wisata dunia. Berdasarkan kebutuhan wisatawan dan kemampuan masyarakat pedagang acung, maka ada beberapa hal yang harus dilakukan, yaitu: memberikan pembinaan tentang pariwisata,memberikan pelatihan bahasa asing dan teknik menjelaskan objek serta produk dalam bahasa asing, dan menciptakan produk yang mampu mencerminkan siri khas objek wisata Desa Penelokan sebagai souvenir.

Perkembangan kawasan agrowisata di Kintamani masih menghadapi berbagai persoalan yang utamanya dihadapi oleh pelaku, yakni petani. Berdasarkan temuan di lapangan, masih banyak ditemukan berbagai kendala yang dihadapi oleh masyarakat desa kawasan agrowisata pada umumnya dan petani pada khususnya. Kendala tersebut dapat dilihat dari berbagai aspek khusus, 
seperti aturan desa dan pengelolaan lembaga sosial dan budaya desa, luas dan kepemilikan tanah,sistem permodalan, pemanfaatan sumber daya, dan sistem penjualan.

\section{Pembahasan Hasil Penelitian}

Berdasarkan hasil penelitian di atas diketahui bahwa terdapat berbagai lembaga sosial dan budaya di desadesa kawasan agrowisata Kintamani, termasuk lembaga pertanian. Namun kelembagaan pertanian di desa-desa tersebut masih belum maksimal. Menuntut Syahyuti(2003) dan Purwanto, dkk (2007), kelembagaan petani di daerah pedesaan, umumnya tidak berjalan dengan baik disebabkan oleh beberapa factor. Pertama yakni kelompok tani pada umumnya dibentuk berdasarkan kepentingan teknis untuk memudahkan pengkoordinasian apabila ada kegiatan atau program pemerintah, sehingga lebih bersifat orientasi program, dan kurang menjamin kemandirian kelompok dan keberlanjutan kelompok. Selain itu, faktor yang menyebabkan tidak berjalannya kelembagaan petani dengan baik yakni partisipasi dan kekompakan anggota kelompok dalam kegiatan kelompok masih relatif rendah, ini tercermin dari tingkat kehadiran anggota dalam pertemuan kelompok rendah. Faktor berikutnya adalah pengelolaan kegiatan produktif anggota kelompok yang bersifat individu. Kelompok sebagai forum kegiatan bersama belum mampu menjadi wadah pemersatu kegiatan anggota dan pengikat kebutuhan anggota secara bersama, sehingga kegiatan produktif individu lebih menonjol.
Faktor keempat yakni pembentukan dan pengembangan kelembagaan tidak menggunakan basis sosial capital setempat dengan prinsip kemandirian lokal, yang dicapai melalui prinsip keotonomian dan pemberdayaan. Selain itu, pembentukan dan pengembangan kelembagaan berdasarkan konsep cetak biru(blue print approach) yang seragam merupakan faktor lainnya yang mempengaruhi ketidak efektifannya suatu lembaga pertanian. Introduksi kelembagaan dari luar kurang memperhatikan struktur dan jaringan kelembagaan lokal yang telah ada, serta kekhasan ekonomi, social, dan politik yang berjalan. Pembentukan dan pengembangan kelembagaan berdasarkan pendekatan yang top down menyebabkan tidak tumbuhnya partisipasi masyarakat, kelembagaankelembagaan yang dibangun terbatas hanya untuk memperkuat ikatan horizontal, bukan ikatan vertikal dan pengembangan kelembagaan selalu menggunakan jalur structural, dan lemah dari pengembangan aspek kulturalnya merupakan faktor selanjutnya yang menyebabkan tidak berlangsungnya lembaga pertanian dengan baik.

Sumber daya dan potensi local kawasan agrowisata daerah Kintamani sebenarnya sudah cukup menjanjikan. Terapat berbagai macam komoditi hasil pertanian yang berkualitas dan kebutuhannya sudah cukup tinggi. Namun, pemanfaatan sumber daya dan potensi tersebut belumlah maksimal. Petani masih belum mendapatkan manfaat yang signifikan dari hasil pertanian tersebut. Hal tersebut disebabkan oleh ketidakberdayaan

Jurnal IImu Sosial dan Humaniora | 390 
mereka dalam melakukan negosiasi harga hasil produksinya.

Posisi tawar petani pada saat ini umumnya lemah, hal ini merupakan salah satu kendala dalam usaha meningkatkan pendapatan petani. Menurut Suardika (2007), lemahnya posisi tawar petani di kawasan agrowisata Kintamani- Bali, umumnya disebabkan oleh petani kurang mendapatkan/ memiliki akses pasar, informasi pasar dan permodalan yang kurang memadai. Petani kesulitan menjual hasil panennya karena tidak punya jalur pemasaran sendiri, akibatnya petani menggunakan sistem tebang jual. Mekanisme seperti tersebut, menyebabkan hamper $40 \%$ dari hasil penjualan panenan menjadi milik tengkulak atau pengepul tani. Sementara Suastawan (2010) dalam paparannya terkait dengan " strategi pemberdayaan lahan agrowisata Kintamani menuju kawasan indusrti pertanian- wisata dunia", menyatakan bahwa: peningkatan produktivitas pertnian tidak lagi menjadi jaminan akan memberikan keuntungan layak bagi petani tanpa adanya kesetaraan pendapatan antara petani yang bergerak di subsistem on farm dan pelaku agrobisnis di subsektor hulu hilir.

\section{SIMPULAN}

Berdasarkan temuan lapangan dan pembahasan sebagaimana yang telah dideskripsikan di atas, maka dapat disimpulkan beberapa poin sebagai simpulan akhir dari penelitian pada tahun pertama ini, yaitu : (1) berdasarkan data Dinas Pariwisata Kabupaten Bangli, terdapat beberapa desa yang telah ditetapkan sebagai destinasi wisata Kintamani Kabupaten Bangli Provinsi Bali, yaitu : desa Batur Selatan, desa Batur Tengah, desa Batur Utara, desa Kedisan, desa Buahan, desa Trunyan, desa Suter, desa Songan $A$, desa Songan $B$, dan desa Kedisan. Secara umum lembagalembaga social kemasyarakatan yang ada di semua desa tersebut hamper sama, hanya struktur organisasisanya yang sedikit berbeda, yang disesuaikan dengan kebutuhan dan kebiasaan masyarakat setempat. (2) lembaga social dan budaya yang terdapat di desa-desa kawasan agrowisata Kintamani, pada umumnya adalah: Sekehe Teruna Teruni, Kelompok Tani, Gabungan Kelompok Tani, Sekehe Joged, Sekehe Santi,Sekehe Tabuh, Sekehe Payus, Sekehe Rejang, Sekehe Manyi, Sekehe Baris, Sekehe, Pruguh, Sekehe Gong, Sekehe Gambuh, Lembaga Perkreditan Desa, Desa Adat, Koperasi Unit Desa, Kelompok Penyakap,dan Kelompok Peternak. (3) pada desa-desa kawasan agrowisata di Kintamani, terdapat lahan yang masih cukup besar untuk dimaksimalkan pemanfaatannya, yakni berkisar antara 10 sampai 100 haktar di tiap desanya. Namun, berdasarkan hasil survey di lapangan, hanya sebagian kecil dari lahan terebut yang merupakan milik penduduk setempat. (4) potensi kekuatan yang dimiliki oleh masyarakt desa penyangga pembangunan pariwisata di kawasan Kintamani pada dasarnya bersandar pada keindahan alam dan modalitas social budaya masyarakat itu sendiri. (5) masih ditemukan berbagai kendala yang dihadapi oleh masyarakat desa kawasan agrowisata pada umumnya dan petani pada khususnya, terutama

Jurnal IImu Sosial dan Humaniora | 391 
pada aspek aspek khusus, seperti: aturan desa dan pengelolaan lembaga sosial dan budaya desa, luas dan kepemilikan lahan, sistem permodalan, pemanfaatan sumber daya, dan sistem penjualan.

\section{DAFTAR PUSTAKA}

Arganta, Komang. 2009. Model pengentasan kemiskinan masyarakat petani di Kabupaten Bangli. Laporan Penelitian. Denpasar: Lembaga Penelitian UNUD.

Amien, M., 2005. Kemandirian Lokal. Gramedia Pustaka Utama. Jakarta.

Atmadja, Dewa Made. 2010. Identifikasi masalah-masalah dasar pengembangan kawasan wisata Kintamani Dilihat dari Keberpihakannya kepada Daerah Penyangga Pembangunan Pariwisata di Kawasan Kintamani. Laporan Penelitian. Singaraja: Lembaga Penelitian Undiksha.

Branson, R E. dan Douglas G.N., 1983. Introduction to Agricultural Marketing, McGraw-Hill Book Company, New York, USA.

Dimyati, A., 2007. Pembinaan Petani dan Kelembagaan Petani. Balitjeruk Online. Balai Penelitian Tanaman Jeruk dan Buah Subtropika Tlekung-Batu. Jawa Timur
Elizabeth, R dan Darwis, V., 2003. Karakteristik Petani Miskin dan Persepsinya Terhadap Program JPS di Propinsi Jawa Timur. SOCA. Bali.

Ginantra, Gede Ketut. 2008. Restrukturisasi Pemberdayaan Kelembagaan Pangan Mendukung Perekonomian Rakyat di Pedesaan dan Ketahanan Pangan Berkelanjutan. Makalah. Dinas Pertanian Provinsi Bali. Denpasar: Bappeda Provinsi Bali.

Jamal, H, 2008. Mengubah Orientasi Penyuluhan Pertanian.

Balitbangda Provinsi Jambi. Jambi Ekspress Online. Diakses tanggal 18 Februari 2008.

Lasmawan, Wayan. 2009. Program pengentasan masyarakat miskin dan penguatan kelembagaan local di Kabupaten Bangli - Bali. Laporan Sibermas. Singaraja: Lembaga Pengabdian Kepada Masyarakat Undiksha.

Masmulyadi, 2007. Membangun Kesadaran dan Keberdayaan Petani. Diakses dari Internet tanggal 14 Maret 2007.

Purwanto; Mat Syukur; dan Pudji Santoso, 2007. Penguatan Kelembagaan Kelompok Tani Dalam Mendukung Pembangunan Pertanian Di Jawa Timur. Balai Pengkajian Teknologi Pertanian. Malang. Jawa Timur.

Jurnal IImu Sosial dan Humaniora | 392 
Payne, M., 1997. Modern Social Work Theory. Second Edition. McMilan Press Ltd. London.

Suardika, Made. 2007. Strategi dan Tantangan dalam Pengembangan Gabungan Kelompok tani (GAPOKTAN) sebagai Kelembagaan Ekonomi di Pedesaan di Desa-desa penyangga industry pariwisata Kintamani. Laporan Penelitian. Singaraja: Universitas Panji Sakti.
Suastawan, Ketut. 2010. Pengembangan model pemberdayaan petani agro di kawasan destinasi wisata Kitamani Kabupaten Bangli - Bali. Singaraja: Lembaga Penelitian Panjisakti Singaraja.

Taylor, D.R.F; dan McKenzie. 1992. Dvelopment from Wihins. Routledge. Chapter 1 dan 10. London. 